\title{
THE RELATIONSHIP AMONGST SOEHARTO, MILITARY, AND MUSLIM IN THE END OF NEW ORDER REGIME
}

\author{
Abdul Haris Fatgehipon \\ Department of PIPS, Social Sciences Faculty, State University of Jakarta \\ pertahanan@yahoo.com
}

\begin{abstract}
In the end of Suharto's authority, he began to embrace the power of Islam; he realized the position of Muslims was very important and strategic. While some high-ranking military, like LB Moerdani felt unhappy with business built by Soeharto's family. Suharto built a new political power through the ICMI (Indonesian Muslim Scholar) organization. The emergence of ICMI has been confronted by much of the military officers, they assessed that ICMI shaped sectarian mindset, Gus Dur as NU leader also did not approve the establishment of ICMI. ICMI was chaired by BJ Habibie who at that time had a special affinity with Suharto that made ICMI has the most important role in Indonesian and clout. At the end of Suharto's power, he embraced the power of the Muslim Civilians, Reviews such as ICMI and Muhammadiyah organization. He tried to minimize the political dependence on the military. Hereinafter, Habibie has successfully elected as a vice president of Indonesia based on the general assembly in 1998, after the riots in May 1998, Habibie replaced Suharto's position that has discharged due to students and citizens' demonstrations. By the pretense of the 1945 constitution, the military endorsed the nomination of BJ Habibie as president.
\end{abstract}

Keywords: Soeharto, TNI (Indonesian military), and Muslims

\begin{abstract}
ABSTRAK
Pada akhir otoritas Soeharto, ia mulai merangkul kekuatan Islam; ia menyadari posisi Muslim sangat penting dan strategis. Sementara beberapa petinggi militer, seperti LB Moerdani merasa tidak bahagia dengan bisnis gurita yang dibangun oleh keluarga Soeharto. Soeharto membangun kekuatan politik baru melalui organisasi ICMI (Indonesian Muslim Scholar). Munculnya ICMI telah dihadapkan oleh banyak perwira militer, mereka menilai ICMI berbentuk pola pikir sektarian, Gus Dur sebagai pemimpin NU juga tidak menyetujui berdirinya ICMI. ICMI dipimpin oleh BJ Habibie yang pada waktu itu memiliki kedekatan khusus dengan Soeharto yang membuat ICMI memiliki peran paling penting dalam Indonesia dan pengaruh. Pada akhir kekuasaan Soeharto, ia memeluk kekuatan Sipil Muslim, Ulasan seperti ICMI dan Muhammadiyah organisasi. Dia mencoba untuk meminimalkan ketergantungan politik pada militer. Selanjutnya, Habibie telah berhasil terpilih sebagai wakil presiden Indonesia berdasarkan sidang umum pada tahun 1998, setelah kerusuhan Mei 1998, Habibie menggantikan posisi Soeharto yang telah habis karena mahasiswa dan demonstrasi warga. Dengan berdasar UUD 1945, militer mendukung pencalonan BJ Habibie sebagai presiden.
\end{abstract}

Kata kunci: Soeharto, TNI, Muslim

\section{INTRODUCTION}

The classical theory in political science pointed out, that political exclusion is the study of how to obtain, manage and maintain the power, this theory was exactly appropriate to analyze and study the strategy used by the president Soeharto in retaining his power as Indonesia's President in a very long period.

Over the 32 years of his power, Soeharto run his leadership with stable, Soeharto can easily control the dynamics and mechanisms of political conflict that 
occurred. Through the General Session of MPR, Soeharto repeatedly elected by acclamation as president. In the New Order era, no figures of political who can be a competitor of Soeharto. Soeharto politically was astute in establishing the relationships with various powers, both of elements of the military community organizations, political parties, and religious leaders.(Yulianto,2002: 351)

At the beginning of Soeharto's power, he used the power of the military officers to sustain his power. The power of Islamic organizations, such as $\mathrm{NU}$ (resurgence of Islamic scholar), $\mathrm{Mu}-$ hammadiyah that was used by Sukarno to destroy the PKI, and the followers of Sukarno has been abandoned. The Military and Golkar party became a major force to support the New Order government.(Anwar,2002: 25-28)

In the end of the Soeharto's era, the military officers have started experiencing burn-out used as a political tool of the New Order. They look at Soeharto's old has already dusk; there should be the alternative presidential candidate. The son, daughter, and grandson of Seharto who build defective business Empire raised public antipathy and the critical of TNI officers. TNI Commander, LB Moerdani, provided suggestion to Soeharto to restrict his children's business expansion. This suggestion responded coldly by Seoharto, even Soeharto began to safeguard the distance to LB Moerdani. Later, Soeharto began leaving LB Moerdani in plots of land; LB Moerdani was eliminated from the vortex of Sandalwood's.

After getting rid the group of General L.B. Moerdani from the center of power, Soeharto built a new political force that base on the power of Islam. President Soeharto began to provide an opportunity for the military officers who used outside of LB Moredani's vicious to hold various important positions.
Golkar party officials began to be held by civilian politicians, mostly activists of Muslim organizations such as HMI (the united of Indonesian Muslim), Muhammadiyah, and ICMI.

Soeharto's political alignments to Islam can be seen as Soeharto's skill in viewing the political change in Indonesia. The development in the field of education by the New Order government has led to a new political force in Indonesia, namely the class of educated Muslims. The Armed Forces began to emerge in the young general who came from Islamic students. Soeharto began to change the course of politics by making political partnership with the power of Islam.

This study aimed to find out: (1) how is the emerging of Soharto in ICMI and TNI, (2) What is the role of Soeharto in ICMI; (3) How is the end of Soeharto's era.

\section{RESEARCH METHOD}

This study applied heuristic approach design to collect primary and secondary data through library research, documentation, and interview. According Kontowijoyo in his book, Pengantar Ilmu Sejarah stated that the methods of historical research through five stages, the selection of topics, the use of sources of (heuristics), verification (historical criticism, the validity of the source), interpretation, analysis and synthesis, and writing and reporting. (Kuntowijoyo, 2013:69-70). In accordance with the title The Relationship amongst Soeharto, the Military, and the Muslim People, at the End of the New Order regime, this paper was included in political history to obtain the data source (heuristic) in the history of politics. The researcher seeks written sources relating to the title of the study to get the resources in several li- 
braries in Jakarta, Indonesia University library, the library of CSIS. The researcher also get several primary sources included documents from government agencies and Parliament. After getting all the written sources and the documents, the researcher conducted a critique of sources, so that the source of which obtained was accountable. The researcher also interviewed a number of political and military figures that breathing an important role during the Soeharto era such Sudomo, Mahfud MD, Amin Rais, and Suadi Marasabessy. The interview result has been crosschecked with various parties in order to minimize the subjective elements. The researcher also conducted interpretation and analysis of data from several data collected the political history of the study hope that the report was a completely objective and can be accounted the truth.

\section{RESULT AND DISCUSSION}

\section{The Emerging of ICMI \& TNI's Re- spon}

To gain the sympathy from the Islamic scholars' power, President Soeharto provided support to Prof. Dr Habibie to establish Ikatan Cendekiawan Muslim Indonesia (ICMI, the Association of Scholar of Indonesian Muslim). ICMI by a group of scholars got the protests from some military officials; by reason that ICMI was a sectarian organization that endangers national unity.

Abdurrahman Wahid did not approve the establishment of ICMI, Abdurrahman Wahid known to have a close relationship with General LB Moerdani and always do a critique of the group of Soeharto and Habibie. The Generals of Islamic group, such as Major General Hartono (East Java Regional
Commander) provided support for the establishment of Soeharto and ICMI. The President expressed his support to ICMI by the legalizing of ICMI.

The majority of military officers see ICMI as a new threat on the Pancasila that has become the state ideology of Indonesia. Secular-minded army officers suspect ICMI as a sectarian organization which endanger the unity of the state and nation, because it only gave priority to the interests of Muslims. The critical attitude of the members of ICMI (Dr. Imadnuddin, Dr. Adi Sasono, and Dr. Amien Rais) rose to the group General LB Moerdani who assessed many human rights violations against the Muslims in the past, further strengthening hatred of TNI officers.(Said, 2001: 211214)

TNI officers regard Gen. L.B. Moerdani as a military leader who has great services to the country and nation. Although General LB Moerdani has retired from the military but still had his influences. The military officers and civilian leaders who disagree with ICMI see the board ICMI and Soeharto has been to manipulate religion for their political interests; it is very harmful to the security of the state.

\section{Soeharto and ICMI}

Dr. Imanudin - in a religious lecture at the mosque of Salman ITB Campus - stated that the reason why ICMI supported Soeharto because he has changed. Soeharto formerly influenced by the group of General LB Moerdani who hate against Islam. Now he turned to defend Muslims. Soeharto had accomplished the teachings of Islam, carried out the Hajj and added his name with Haji Muhammad Soeharto. The Muslims should be aware that there are political changes (CD Imanuddin, 
Mosques of Institute for Technology Bandung: 1990).

ICMI was established with the intention of bringing together scholars to provide benefits to the advancement of religious, economic, and development of Muslims in Indonesia. The colonialization of Netherland was so long in Indonesia has led to Muslims are lagging behind in many fields, especially education and economy. The establishment of ICMI was expected to encourage the advancement of Muslims in Indonesia. ICMI was not originally intended to enter the political realm, but political changes in that time since President Soeharto began to stand up with Muslims, so that it drive ICMI directed to support Soeharto.

Alamsjah Ratoe Perwiranegara in his biography book identifies Muslims in Indonesia already has a lot of scholars, but they are not united and disagree with each other. If Muslim scholars would come together, it can help to overcome poverty, ignorance and backwardness facing Muslims in Indonesia. (Prawiranegara,1995:326)

The alignments to Muslims at the end of Soeharto's New Order may be due of two reasons. First in Javanese cultural tradition of a king before the old days are getting close to the religion (be pandito). (Dwipayana,1989:561-567). Soeharto who tend to practice the Javanese mystical beliefs, which he has realized twilight (70 years) he had to get closer to the Creator (Barton, 2004: 204 207). Second, at the end of Soeharto's New Order, military officers holding positions (group of General Benny Moerdani) has begun to be critical of mistakes made by Soeharto' family in the business.

The members of ICMI have two groups with differing political views. The first group consists of scientists, such as Prof. DR. Amin Rais, DR. Sri
Bintang Pamungkas, argued that although Soeharto support ICMI, but they remain critical of the New Order are assessed a lot of corruption, oppression, and injustice. The second group view ICMI should be cooperative to against Soeharto policies (in collaboration with Soeharto). Once in power they would make changes. Members of this group, among others, Prof. Dr B.J. Habibie, Prof. Dr Muladi, Dr. Ahmad Watik Pratiknya, Dr. Dewi Fortuna Anwar. Prof. Dr B.J. Habibie (Minister of Research and Technology) has long been considered a political opponent by the group General LB Moerdani, B.J. Habibie, who was considered too much interference in military affairs, for example in the case of the purchase of the German's ex-warships.

Prof. Dr B.J. Habibie tried to build influence in the armed forces influencing President Soeharto to induct Commander of the Armed Forces from the group that had closeness with ICMI. Many of ABRI leaders criticized Prof. Habibie as judged sectarian (pro-Islam).

On May 21, 1993, Lieutenant General Faisal Tanjung inaugurated by President Soeharto as Armed Forces Chief replaced Gen. Edi Sudrajad (accomplice of General Benny Moerdani), followed also with the inauguration of various important positions in the military, which is occupied by high military officers who have a close relationship with Soeharto and Habibie.

The relations of Prof. Dr B.J. Habibie and the Indonesian army were harmonious after the General Faisal Tanjung was the chief of the Armed Forces. Prof. Dr B.J. Habibie and General Faisal Tanjung tried to build military confidence against Muslims. During this time the Indonesian army was always suspicious of Muslims.

There are two possibility causes for the emergence of the Indonesian ar- 
my suspicion against Muslim: First, historically unheard of armed conflict between opposition forces who use the name of Islam. Armed conflict has been completed but the ideological conflict between Islam and the Indonesian soldiers continue to emerge. Each time, the Islamic political group wanted the principle of Indonesia is Muslim, while the Indonesian army retains Pancasila as the unitary state of Indonesia. Second, there are other forces that want to create a conflict between the army and the Muslims, with the intent to gain political advantage from the conflict between the Indonesian army and Islam ( Hisyam,1999: 498).

The support of Armed Forces Chief (General Faisal Tanjung) for the spread of the teachings of Islam to the soldiers cannot be released by the interests of Soeharto to build support from Islamic groups. President Soeharto, who began to feel, threatened his position to seek support from the Muslims. Soeharto provides the opportunity for Muslim scholars and students of Islamic army officers to hold various positions in the army and government, in hopes of getting the support of Muslims for reelection as President.

In the era of General Faisal Tanjung, an important positions in the majority of Indonesian army officers held by green groups (Islam), which has a close relationship with the people of the Islamic Armed Forces. The military officers derived from red-white groups (nationalist, Christianity, Islam abangan) discharged from the circle of Cilangkap (TNI headquarters). This situation led to the emergence of friction between the officers of the group of red-green and white (Barton , 2004: 279). These were a strategy of Soeharto to continue to dominate the military. If the army officers united, then Soeharto had difficulty in mastering the army, and the army can be a threat against Soeharto.

Although Soeharto inclined to green army group, but he maintains and provides an important position to the officers of the red and white groups are considered loyal to Soeharto, such as the General Wiranto. It shows Soeharto impure motives to defend the interests of religion, but is strongly influenced by political interests.

To be able to keep control of Golkar, Soeharto through Habibie provides support to Harmoko, so elected as Chairman of Golkar. Their supports to Harmoko drive to a protests from the Retired Armed Forces. They assess the Golkar chairman shall be held by a group of retired Armed Forces, on the grounds that the army has merit in the establishment of Golkar. Harmoko as civil parties considered has no the ability to lead Golkar.

The armed Forces Chief, Gen. Faisal Tanjung had disagreements with military retirees. General Faisal Tanjung judge, it is fitting to Golkar party to lead by civilians. Civilian and military issues was time for no longer debatable. General Faisal Tanjuang feels confident of Harmoko's ability to lead Golakar (Hisyam, 1999: 558-565 ). The support provided by Soeharto to Harmoko as the Chairman of Golkar was a form of unbelief Soeharto to Golkar officials from the military element.

At the end of the New Order rule of 1996-1998, President Soeharto, who has the support of the Indonesian army tried to cling to power, and there are no signs to make the turn position of presiden. The Indonesian society already saturated against Soeharto and his family that was assessed many corruption and being selfish

The ICMI member, Dr. Sri Bintang Pamungkas and Dr.Amin Rais took a stand against the power of Soeharto. Sri later dismissed as ICMI members and 
members of the House of PPP (opposition party). The discharging of Sri Bintang from members of Parliament shows that the opposition parties were remained by New Order government. Dr. Sri Bintang Pamungkas then arrested and imprisoned by the soldiers.

Amin Rais who was also a member of Muhammadiyah, in the early of January 1997 criticized the mistakes made by foreign investors and Soeharto's family. Amin Rais assessing, in the mining profit sharing in Timika Papua, the Indonesian government only gets the benefit of $10 \%$. So also with the management of mining in Busang Borneo, which is assessed by Amin Rais, only gave the benefits to the Soeharto's family and his cronies. In the design of the distribution of mining shares in BreX Busang Company holds a $45 \%$ of share. (Syam,2003: 208)

The criticism of Dr. Amin Rais raised ire of Soeharto. Soeharto was very sensitive when there was criticism directed against his family. To maintain good relations with Soeharto, ICMI officials dismiss Amin Rais from the Chairman of the Board of Experts of ICMI. After his discharging of the Chairman of the Board Experts of ICMI, he even dares to criticize the President Soeharto. DR. Amin Rais - in a variety of formal lectures - demanded the turn of the President of Indonesia (succession). Although Dr. Amin Rais critiques of the political role of the military (the dual function of the Armed Forces), but he was not breathing detained by security forces. Amin Rais who is the chairman of Muhammadiyah has the strong support of the Islamic masses, because the government does not want to take the risk to collide with the power of Islam. (Syam , 2003: 197-200)

\section{End of Soeharto's Power}

The riots and demonstrations in May 1998 became a deadly blow for Soeharto's power Seharto, however, Soeharto in many ways still good trying to persistence. Soeharto's made political approach with Muslim leaders by invited them to the state palace. During the meeting, Dr Nurcholish Madjid stated politely, preferably Soeharto resigned as president. Soeharto responded to the statement of Dr. Nurcholish Madjid with a smile and said that the elections would be held as soon as possible, he will not nominate for president. Soeharto also requested that Muslim leaders want to support themselves form the reform committee. The Muslim leaders rejected the demand of Soeharto to provide political support. The Muslims in Indonesia have an influential role in any political change.

After the meeting with the Muslim leaders, President Soeharto spoke expressing the heaviness of his heart to resign from the presidency. He did not want to say - in the Java language Tinggal glanggang colong playu (fled the arena or responsibility). Soeharto doubts the ability of BJ Habibie to replace him. He said he will continue to lead and implement the reforms by establishing Reform Committee whose members come from community leaders and scholars. The task was complete the reform committee election law, statute party, law arrangement MPR, DPR, and the Parliament, the anti-corruption legislation. President Soeharto also will implement the change cabinet reshuffle. Development Cabinet changes will change its name to Reform Cabinet. President Soeharto asked the army and police to maintain security of the state along with all the people.

The statement of Soeharto shows the attitude in cooperation with the de- 
mands of students demanding reform, in contrast with Soeharto statement two months ago that claimed the reforms will be implemented in 2003. (Emmerson,2001:553) The change in political attitudes showed Soeharto has been in a weak position. Soeharto tried to retain power, amid political pressure and public student who asked him backwards. Soeharto statement doubted the ability of Habibie bring disappointment and anger of BJ Habibie who has long considered Soeharto as a teacher.

Despite the political behavior of BJ Habibie, who impressed close to Islamic groups critical and less favored by some military officers, but Habibie gain political support from military leaders to positions presiden. This because first, is oriented to the Pancasila ideology army and Law 1945. In the Act of 1945 stated that the President stopped from office, the Vice-President who will replace him. Second, the military officer who occupy important positions in the time it has a good relationship and communication with BJ Habibie, for example Pangkostrad Lt. Gen. Prabowo, who on many occasions has always expressed himself very awe, respect, and considered BJ Habibie as his parents. (Zon, 2004:147)

Although Soeharto resigned as president, but most students refused to leave the DPR/MPR' building, by reason of BJ Habibie is a henchman of Soeharto. Soldiers who had expressed his attitude to admit Habibie as president-along with the Islamic organization, exert pressure on the students to leave the DPR/MPR. Abdurrahman Wahid invited the community to support Prof. Dr BJ Habibie as President, in honor of the Constitution of 1945. Dr. Amin Rais said that he welcomes the attitude of Soeharto to resign from the presidency.(Zen, 2004: 88-89)

Dr. Amin Rais support Habibie was sworn in as President of the transitional (temporary). He expected President BJ Habibie immediately eradicate corruption, collusion, and nepotism in Indonesia. The retired General AH Nasution said all parties should provide the opportunity for BJ Habibie to lead Indonesia, and should thank Soeharto would resign. Abdul Qadil Jilani assess BJ Habibie was sworn in as president should be welcomed by the people of Indonesia, especially Muslims. Muslims have long been waiting for political reform, economic, and legal in Indonesia. (Bakti, 1999:273-274)

\section{CONCLUSION}

The Muslims in Indonesia have a very high influence in political change in Indonesia, the formation of the New Order government was inseparable from the role of Muslims, and the Muslim people feel they were less given the opportunity to participate in the New Order government. In the end of Soeharto's power, he tried to establish an approach to the strength of the Muslims; he agreed and supported the establishment of ICMI organizations, the Association of Indonesian Muslim scholar. ICMI was chaired by BJ Habibie, became very religious social organization that has most influence at that time. The defective business empire built by the Soeharto's family made antipathy among military officers. This was one of reason of Indonesian people doing demos for lowering Soeharto. Some of TNI officers were getting fed manipulated by the New Order government, they believe that Seharto, in the near future definitely stop of his power because of his age. They assessed Soeharto not nominated for president again, but none of the military officers who dared to express directly their opinion to Seharto. 
The events of May 1998 ended Soeharto's power. Although many people did not like BJ Habibie, but the constitution, civilian and military leaders, respect to country constitution of Law 1945, which set, if the president remains incapacitated, then replace it by the vice president.

\section{REFERENCES}

Anwar, Dewi Fortuna. 2002. Gus Dur Versus Militer. Jakarta: Grasindo Press.

Bakti, Ikrar Nusa. 1988. Tentara Yang Gelisah. Jakarta: Mizan.

Barton, Greg. 2004. Biografi Gus Dur, Yogyakarta:LKIS

Dwipayana, G. dan Ramadhan K.H. 1998. Biografi Soeharto Pikiran, Ucapan dan Tindakan Saya. Jakarta: Citra Lamtoro Gung Persada.
Emmerson, Donald K. 2001. Indonesia Beyond Soeharto. Jakarta: Gramedia.

Hisyam, Usamah. 1999. Faisal Tanjung, Terbaik Untuk Rakyat Terbaik Bagi ABRI. Jakarta: Darmapena

Kuntowijoyo. 2013. Pengantar Ilmu Sejarah, Yogyakarta: Tiara Wacana

Prawiranegara, Ratu Alamsyah. 1995. Perjalanan Seorang Anak Yatim. Jakarta: Pustaka Sinar Harapan.

Said, Salim. 2001. Militer Indonesia dan Politik.Jakarta: Pustaka Sinar Harapan

Syam, Firdaus. 2003. Amien Rais Politis Yang Merakyat \& Intelektual Yang Saleh. Jakarta: Pustaka Alkausar

Yulianto, Arif. 2002. Hubungan Sipil Militer di Indonesia Pasca Orde Baru. Jakarta : Grafindo.

Zen, Kivlan. 2004. Konflik dan Integrasi TNI$A D$. Jakarta: IPS.

Zon, Fadli. 2004. The Politics of The May 1998 Riots, Jakarta:IPS 